\title{
Some Back-Ended Legal and Political Issues in United States Fisheries Management
}

\author{
Chad McGuire (Corresponding author) \\ Department of Public Policy, University of Massachusetts, Dartmouth \\ 285 Old Westport Road, Dartmouth, Massachusetts 02747, United States \\ Tel: 1-508-999-8520Ｅ-mail: cmcguire@umassd.edu
}

Bradley P. Harris

Department of Fisheries Oceanography, School of Marine Science and Technology

University of Massachusetts, Dartmouth

706 South Rodney French Blvd., New Bedford, Massachusetts 02744, United States

Tel: 1-508-910-6359_E-mail: bharris@umassd.edu

\begin{abstract}
In response to resource over-exploitation and ecosystem degradation, United States federal fisheries policy is shifting from species-based to ecosystem-based management. In addition, the reauthorized Magnuson-Stevens Fisheries Conservation and Management Reauthorization Act of 2006 identified the following goals to be achieved by 2011: end over-fishing, create market-based incentives, strengthen enforcement mechanisms, and improve cooperative conservation efforts. We refer to these goals (including the "status quo") as front-ended policy objectives. Left unresolved are what we term back-ended policy and legal issues, specifically including issues involving the legal limitations that inhibit full consideration of ecosystem-based management principles through the adopting of scientific information. In this paper, we identify and examine some of these legal limitations, including the standard of review used in judicial proceedings. In addition, we also suggest some potential solutions to these major governance obstacles. We believe the ultimate value of this paper is the identification of recurring framework issues in United States fisheries management if, left unresolved, will continually limit the conservation-related goals such as those identified in the Magnuson-Stevens Fisheries Conservation and Management Reauthorization Act of 2006. As such, these legal obstacles should be a primary focus of policy makers who wish to achieve fishery conservation goals in-line with scientific research.
\end{abstract}

Keywords: Law, Policy, Fisheries Management, Ecosystem-Based Management

\section{Introduction}

The purpose of this paper is to identify what we term back-ended legal and policy issues of current United States fishery management, specifically management goals based in ecosystem principles. We use the term back-ended in reference to issues created by the interactions of substantive and procedural statutory requirements, social philosophies inherent in agency regulations, and the standard(s) of judicial review of agency actions. Here we identify back-ended issues resulting from application of the precautionary approach in the jurisprudential frameworks of the Magnuson-Stevens Fisheries Management Act (Magnuson-Stevens Act) and the National Environmental Policy Act (NEPA). A conceptual rendering of the issue dynamics is shown in Figure 1.

United States Federal Courts are responsible for ensuring agency compliance with statutory goals. This judicial oversight comes from the separation of powers doctrine, which emanates from the United States Constitution. Since agencies are part of the executive branch of government, their actions must derive from either direct constitutional power, or from the indirect granting of power from the legislative branch. This indirect grant of power includes a legislative delegation of authority to agencies. In summary, a legislative body, upon passing a law, can delegate the implementation of that law to an executive agency - the so-called delegation power. However, agencies cannot go beyond the boundaries of that grant of power - they cannot exceed the statutory power granted to them by the legislation. The judicial branch is empowered to review agency conduct to ensure the executive branch has not exceeded a statutory grant of power from the legislative branch. To place this summary in relevance, most environmental laws in the United States, including federal laws passed to regulate fishing activities, are implemented through a delegation of power to the executive branch.

Fisheries management law in the United States requires, among other things, that management decisions be based on the best available scientific evidence. Considering, for example, the limited scientific information 
available for essential fish habitat assessments, agencies are left interpreting the information they have through a veil of precaution. (Note 1) The current judicial standard of review allows for a strong deference to agency scientific interpretations. Any lack of scientific information may be creating a new view of science from a jurisprudential standpoint in which the intent of the legislative branch is being missed by the dynamic nature of the science, the existing executive agency approach to uncertainty, and the conflicting review standards set forth in applicable federal statutes. In short, to meet the current goals of federal fisheries law (end overfishing and improve conservation efforts) under existing legal frameworks, agencies must identify many decisions as being based in science, even when science might not support the decision. Most importantly, because of a deferential judicial review process of agency action, decisions that are not founded in science are being judicially determined to meet best scientific evidence standards. This is establishing precedence where executive agency acts are arguably outside legislative branch delegations, creating a powerful agency decision maker in the field of federal fisheries management.

We propose Congress either amend the standard of review available to courts when considering what constitutes best scientific evidence, or set forth a more detailed statutory definition of "best scientific information available" under federal fisheries law. This likely includes statutory amendments prioritizing the requirement that federal agencies re-evaluate management decisions when new or better scientific information is made available. The current path of judicially supporting agency decisions as "science" under the current statutory requirements, if left unresolved, will only support continued agency decision-making based on low scientific rigor, and decrease critical review of status quo designations.

The sections of this paper are separated as follows. We begin in Section 2 with the development of United States fisheries policy, identifying the change in management goal from species-based to ecosystem-based management. In Section 3 we discuss the development scheme for best scientific information available at the administrative or federal agency level. Section 4 presents some back-ended issues associated with habitat designations. Section 5 provides an overview of the judicial standard of review used to interpret agency decisions, and we discuss the potential implications for implementing scientific standards under this standard of review. Finally, in Section 6 we offer several suggestions for improving administrative decision-making within the jurisprudential context.

\section{The Shift from Species-Based Management to Ecosystem-Based Management in United States Fisheries Policy}

The predominant fisheries management paradigm is shifting from species-based to ecosystem-based management, including the use of geospatial management measures like Marine Protected Areas (Sissenwine \& Mace 2003, NOAA 2005). This change has increased the demand for place-based knowledge of why, when and how fishery species interact with the marine environment. The impetus for this change in management direction derives primarily from amendments to federal laws that regulate fishing. For example, the 1996 Sustainable Fisheries Act amendments to the Magnuson-Stevens Fisheries Management Act (Magnuson-Stevens Act) required essential fish habitat to be identified and mapped for every federally managed commercial fishery species by life stage (50 CFR $\S 600.815(a)(1)$ ). Further, in 2000, then President Clinton signed Executive order 34909 instructing federal agencies to strengthen marine resource management, protection, and conservation via science-based identification and prioritization of natural and cultural resources. This executive branch order stressed the use of science-based criteria and protocols for monitoring and evaluating marine resource protection effectiveness (Federal Register Vol. 65, No. 105, available at: http://mpa.gov/pdf/eo/execordermpa.pdf). More recently, there has been international movement to change from single-species to "an ecosystem approach" or "ecosystem-based" management practices.

The Magnuson-Stevens Act uses fisheries management plans to implement fisheries policy including harvest limits, essential fish habitat evaluation, geospatial fishing restrictions, and further requires that management plans be based on the best scientific information available. Additionally, each plan is considered a major federal action, triggering an additional review process under the federal law know as the National Environmental Policy Act, or NEPA for short. (Note 2) Regional Fishery Management Councils, under the oversight of the federal fisheries agency, NOAA Fisheries, generally adjust or amend management plans, triggering frequent NEPA reviews.

A large part of developing fisheries plans under the new federal law requires a detailed understanding of how fishing fits into marine ecosystems, especially the links between target fish species and their habitats. Due to the complexity of marine environments, scientific knowledge of these ecosystems remains limited (National Research Council, 2006). Indeed, few existing scientific studies have examined the marine environment at the scales necessary to adequately cover fishing ground contained in management plans (typically $1000-100000$ 
$\mathrm{km}^{2}$ ). As such, meeting a "scientific" standard as required in the federal law is difficult, simply because adequate scientific studies are lacking. In the face of such limitations, the executive branch has often adopted fishery management plans that lack substantial scientific support, even though the legislative mandate under the law calls for these plans to be based in science (Mace \& Gabriel 1999, Holliday \& Gautam 2005). This has led, for example, to the closing of certain fisheries for less than scientific reasons, as well as the redistribution and concentration of other fisheries in open areas (Murawski et al., 2000).

\section{Federal Executive Agency Development of Best Scientific Information Available}

The use of science in fisheries management has evolved in the face of uncertainty, including implementation at the agency regulatory stage. Federal fisheries law first mandated the use of "best scientific information" by requiring that "[c]onservation and management measures shall be based upon the best scientific information available" (16 U.S.C $§ 1851(a)(2))$. The federal judicial branch has interpreted this federal statutory language by emphasizing the term "available," stating: "By specifying that decisions be based on the best scientific information available, the Magnuson-Stevens Act recognizes that such information may not be exactly or totally complete" (Midwater Trawlers Coop. v. Department of Commerce, 393 F.3d 994, 1003 ( $9^{\text {th }}$ Cir. 2004)). Moreover, these same courts have indicated a lack of scientific information does not prevent regulation, and therefore executive branch regulation in the face of scientific uncertainty has been permitted in the fisheries management laws of the legislative branch (Midwater Trawlers Coop., 393 F.3d at 1003 (emphasis in original)). This is in-line with the executive branch regulations established regarding the standard of scientific certainty required for management purposes: "The fact that scientific information concerning a fishery is incomplete does not prevent [regulation]" (50 CFR $\S 600.315(\mathrm{~b})$ ). However, when establishing the original standards, the Senate Commerce Committee indicated the "best scientific information available" standard "must be recognized as one of the most important standards" (Senate Committee, Fishery Conservation and Management Act, 94). Thus, there is support in the Congressional record to indicate that a primary function of fisheries management is the identification and application of scientific rigor to support fishery management plans.

Thus, the standard of scientific rigor has been determined by both the judicial and executive braches of government to be directly related to the state of the science and is therefore variable. If the science is good, then a greater degree of rigor is likely required. Conversely, where the science is lacking, a lesser degree of rigor will not prevent regulation from moving forward, even when the management plan contains limits to fishing certain areas that are not based on sound scientific principles. This is profound, especially when one considers the legislative requirements in the law call for management plans to be supported by science. For example, Pikitch et al. (2004) has suggested, to be scientific, decisions implicating ecosystem-based management must "delineate all marine habitats utilized by humans in the context of vulnerability to fishing-induced and other human impacts, identify the potential irreversibility of those impacts, and elucidate habitats critical to species for vital population processes." Based on Pikitch's definition of ecosystem-based management for fisheries, cause and effect relationships must be established between the services marine habitats provide to species and how anthropogenic activities impact those services. The implication is that management plans attempting to identify (and regulate) essential fish habitats are currently doing so without much scientific rigor. This suggests the executive branch is effectively regulating fisheries in a manner that goes against the scientific principles that have been highlighted by the legislative branch in its recent amendments to the fisheries management laws. In addition, there seems to be an acceptance by the judicial branch of this practice, as highlighted in the examples above. The result seems to be a situation where federal fisheries management is being implemented by the executive branch of government in a manner that goes beyond the power to do so granted by the legislative branch. Most importantly, the judicial branch seems unwilling to acknowledge this fact, mostly because there is limited scientific information available to make honest and accurate fisheries management decisions, at least on the larger scales identified above.

\subsection{Applying Science to Identify and Protect Essential Fish Habitat}

Under essential fish habitat provisions of the federal Magnuson-Stevens Act, executive branch regulation of fisheries was to expand from the traditional management of fishery harvests to a focus on fishery habitat. Specifically, Magnuson-Stevens mandated federal agencies "....minimize, to the extent practicable, adverse effects on habitat..." (16 U.S.C. §1853(a)(7)). To do this, federal regulations were to be developed to assist regional fishery councils in the description and identification of essential fish habitat in fishery management plans (16 U.S.C. §1855). Once essential habitat is identified, councils are to consider the adverse fishing impacts on the habitat, and to ensure the conservation and enhancement of such habitat. From a policy perspective, it can be assumed that identifying essential fish habitat, no matter the methodology employed, is a front-ended process that will result in labeling an area of the ocean as a place where restrictions on fishing effort are expected. It is 
generally difficult to remove a label of protection once it has been put in place, regardless of the scientific basis for the original designation. For example, the New England Fishery Management Council closed three fishing areas in 1994 (Murawski et al., 2000). Portions of these areas were reinforced as "Habitat Closures" in 2003 (NOAA, 2003), and this was all done based on a set of scientific assumptions that have not been revisited in over sixteen years.

The executive branch regulations define essential fish habitat as follows: “...those waters and substrate necessary to fish for spawning, breeding, feeding, or growth to maturity... necessary means the habitat required to support a sustainable fishery and the managed species' contribution to a healthy ecosystem" (50 CFR $\S 600.10)$. In those same regulations, Regional FisheryCouncils are required to: (1) identify essential fish habitat; and (2) minimize the adverse affects to this habitat through fishing (50 CFR §600.815). These regulatory pronouncements are highly scientific, meaning they require a strong causal connection as described by Pikitch, et al. (2004) above. However, as has been shown, both the federal regulatory bodies and the judicial system do not require a high degree of causal relation when defining "best scientific information" under the Magnuson-Stevens Act. Many in this field acknowledge current habitat decisions are being made with less than optimum information, and often without scientific rigor (National Research Council, 2002). While it certainly may be an acceptable policy practice to adopt precautionary measures for the protection of fishery resources, such actions are not inherently scientific, but nevertheless have strong policy and legal implications. For example, by couching such policy decisions in terms of science, we are creating a scenario where the executive branch is being allowed to act outside legislative intent, which is further being enforced by a judicial branch that defers to executive branch definitions of what is an acceptable level of scientific rigor. This is what we term back-ended issues, and is the remaining focus of this paper.

\section{The Back-Ended Issues Associated with Essential Fish Habitat Designation}

Laws passed by the legislative branch of government represent an official policy statement toward the subject matter of the legislation. In the context of fisheries management, the United States Congress has set a general goal of establishing sustainable fishing practices. At the heart of modern fisheries management is the reliance on science to achieve management goals. However, faced with the scientific uncertainties underlying habitat and ecosystem information, the executive branch is moving forward to implement ecosystem-based management with reduced reliance on science. This is not because the executive branch seeks to avoid good scientific information to inform decision-making. Rather, there is a current lack of scientific information in this field from which to make meaningful decisions (National Research Council, 2006). This reality favors a trend of couching decisions as scientifically based, when actual scientific support is lacking. The undoubtedly unintended back-ended result is the use of the term science to support a non-scientific decision about where to limit fishing. Limited judicial review focused on the quality of the science reinforces this process, while "forcing" mechanisms under certain federal laws such as NEPA create incentives to move forward in designations and management without the benefit of scientific analysis. The two forces then, limited judicial review and "procedural forcing" mechanisms under NEPA, may be seen as drivers reinforcing management decisions without sound science.

\subsection{How "Best Scientific Evidence" is Being Interpreted by Agencies}

A review of the summative literature suggests the executive branch agency responsible for implementing federal fisheries law, NOAA Fisheries, is generally underfunded and understaffed, and therefore unable to properly implement the rigorous details of ecosystem-based analysis (National Research Council, 2002, pgs. 34-35). Complicating NOAA Fisheries responsibilities is the fact that while the federal fisheries law provides specific guidelines for the development of fishery management plans, no guidelines exist for the evaluation of how aspects of such management plans, including the choosing of essential habitat, are made. The result is federal agencies creating rules that interpret best scientific information available to be the level of science currently available, regardless of its rigor, limiting the importance of science as a primary factor in establishing habitat and ecosystem boundaries (National Research Council, 2004).

A primary example of how information has been misused can be found in recent habitat designations. As mentioned above, following the legislative branch amendments to the federal fisheries laws in 1996 and 2006, the emphasis has changed from species-based to ecosystem-based management techniques. The old science used under the species-based management method was primarily stock assessments. The foundational data for these assessments included notations of where a particular species of fish was found in previous years based on annual federal agency surveys. When the management focus incorporated habitat considerations, the main scientific information available only provided information on where species were found, not necessarily the essential 
habitat for that species. (Note 3) Reliance on stock assessment data (where numbers of fish are found) as a proxy for identifying essential fish habitat (what areas are most important for the survival of that fish species) has resulted in regional councils identifying almost the entire area within their jurisdictions as essential habitat, which followed federal executive branch guidelines (for interactive EFH maps see http://sharpfin.nmfs.noaa.gov/website/EFH_Mapper/map.aspx).

This massive designation has caused two back-ended issues. First, these areas have now presumptively been determined to contain essential fish habitat. This means wide swaths of potentially valuable fishing ground are protected under this presumption. Most importantly, the designations are presumed to be based on science, even where the science being employed is entirely unrelated to the protections being created. In the American legal system, it will be difficult to overcome this presumption.

Second, the judicial branch, through legal opinions, has supported these designations as being within the bounds of executive branch discretion, based on legislative intent. The effect of this support suggests that when the executive branch attaches scientific meaning to essential habitat designations, a potentially arbitrary designation becomes veiled as science. Thus, the level of scientific rigor required to support agency decisions has been reduced. With judicial approval of such actions, it can be argued true science is being de-emphasized from the process of habitat designation. Without a strong political will, it is plausible to assume increased scientific rigor will not be a top priority, especially where funding, expertise, and the reality of the kind of science required (data intensive with significant analysis) all suggest a lower likelihood of increasing the state of scientific knowledge and increasing reliance on the social philosophy of precaution.

Regional fishery councils are instructed to examine all available information including peer-reviewed literature, unpublished scientific reports, data files of government resource agencies, fisheries landing reports, and other sources of information, and the consider the information according to its scientific rigor (50 CFR $\$ 600.815(\mathrm{a})(1)(\mathrm{ii})(\mathrm{B}))$. This process is supposed to ensure the best scientific information available was used in the decision-making process. However, as was indicated above, the available information is rarely conclusive from a scientific standpoint. How then are Councils supposed to prioritize this information? Do they grant greater weight to NOAA Fisheries analysis? Do Council technical teams do their own "science"? Or, do they simply conduct an information gathering exercise to satisfy the administrative requirements of NEPA? If the answer even hints towards a tendency to simply gather information (as a proxy for scientific analysis), then we must ask the influence of goal-orientated motivations in the rulemaking process. More importantly, we may see a trend being established where agencies are substituting data accumulation for the legislative branch mandate requiring best available science. Assuming the judicial branch grants deference to such actions, an important lesson is learned: when implementing data-intensive and difficult scientific principles involving ecosystem interactions, the simple accumulation of data, with little actual analysis, can substitute for scientific rigor. The implication is the goal of science informing policy has been abandoned, and instead the collection of information becomes the main function of the decision-making process.

This back-ended issue may be occurring for a variety of practical and politically motivated reasons that are specific to each regional council and NOAA Fisheries regional office or science center. However, the judicial approval of such practices is one check-and-balance that seems to be failing the original intent set by Congress. Moreover, we see conflicting federal standards of review under fisheries laws and NEPA that may incentivize the collection of data over the analysis of that data. If this is true, it brings forth probably the most significant back-ended issue for consideration: an emphasis on complying with federal procedural statutes to defend against judicial challenges taking precedence over the selection of the best information based on its scientific rigor. To develop the rationale for this possibility, we examine the judicial standard of review that is generally applied to fisheries management EFH decisions. The purpose is to identify how the various statutes being applied to fisheries, with their different standards of review, might be impeding the development of ecosystem science.

\section{The Judicial Standard of Review}

\subsection{Presumptions of Judicial Decision-making}

We begin with the premise that executive branch agencies are making geospatial designations using information with insufficient scientific rigor to fully inform their decisions. We further presume the intent of legislative branch, especially in recent federal fishery management laws, are to be informed by science. (Note 4) From these presumptions, we now look at the manner in which the judicial branch has interpreted agency designations of essential fish habitat. When looking at these cases, we want to distinguish judicial review under Magnuson-Stevens Act standards, and judicial review under NEPA standards. In general, we believe courts are deferential to the executive branch when reviewing management approaches under Magnuson-Stevens Act 
(which requires a science-based approach), but are more critical of such decisions under NEPA (which requires certain procedures are followed to ensure the protection of the environment - see Figure 1 and Note 2). Most importantly, the "critical" judicial review under NEPA is focused on ensuring the agency has engaged in a "hard look" at all available information. We believe this standard creates incentives for the executive branch to initially over-designate essential fish habitat under Magnuson-Stevens, but at the same time discourages the executive branch from changing these designations should better scientific information become available.

\subsection{The Doctrine of Deference in Judicial Review}

Historically, courts have appeared unwilling to delve into the details of fisheries management, including determining whether or not the best available science is being applied to support a given management decision (Greenberg, 1993). This unwillingness is generally referred to as the Doctrine of Deference (Coggins, 1998). It is a legal doctrine derived from the field of Administrative Law, and codified under the Administrative Procedures Act (APA). Under the APA, a court will uphold an agency's decision unless the agency is found to have acted arbitrarily, capriciously, with an abuse of discretion, "or otherwise not in accordance with law" (5 USC $\S 706(2)(\mathrm{A}))$.

The judicial interpretation of the Doctrine of Deference has been defined most recently by the U.S. Supreme Court decision in Chevron U.S.A. Inc. v. Natural Resources Defense Council, Inc., 467 U.S. 837, 104 S.Ct. 2778, 81 L.Ed.2d 694 (1984). Under Chevron, the judicial branch is limited in its review of an executive branch interpretation of a legislative branch statute that the executive administers. The Court in Chevron articulated a two-step process in identifying the limitation on judicial review. Under the first step, the reviewing court "must first exhaust the 'traditional tools of statutory construction' to determine whether Congress has spoken to the precise question at issue" (Natural Resources Defense Council, Inc. v. Browner, 57 F.3d 1122, 1125 (D.C. Cir. 1995), quoting Chevron, 467 U.S. at 843, n. 9, 104 S.Ct. 2778). If the statute is silent or ambiguous on the issue, then Congress is deemed to have not spoken directly, and a permissible agency interpretation of the statute merits judicial deference. Under step-two considerations, courts will generally defer to an agency's interpretation if the interpretation is reasonable and consistent with the statutes goals, as determined through an examination of its legislative history. To summarize then, courts will review an agency action by: (1) ensuring that action does not conflict with a clear and direct congressional mandate; and (2) if there is no clear congressional mandate, the court will uphold the agency decision so long as it reasonably relates to the general goals set forth by Congress when it created the statute.

\subsection{Application of The Doctrine of Deference to Federal Fisheries Management}

Concerning federal fisheries management, judicial review has taken on differing levels of importance, depending on which statute is being reviewed. Reviewing the "best scientific evidence available" standard under Magnuson-Stevens, courts have generally been unwilling to alter agency decision-making procedures. Such review should not be confused with the recent trends in litigation after the implementation of the Sustainable Fisheries Amendments of 1996 to fisheries management. The amendments may be seen as a re-codification (and therefore re-prioritization) of ecosystem-based principles through the identification and conservation of EFH. Researchers have highlighted the increase in judicial scrutiny applied during this time (National Research Council, 2002). However, much of this additional scrutiny involves the review of other federal statutes, including the National Environmental Policy Act (NEPA). NEPA has different congressional goals than Magnuson-Stevens, and therefore, the courts review can be seen as more far-reaching, at least when one is focusing on the scrutiny given to achieve the goal of essential fish habitat designation and management. Since the Sustainable Fisheries Act makes identification of essential habitat a priority, NEPA can be used to force designations, including designations made without sufficient scientific rigor. A review of some recent cases attempting to resolve essential fish habitat designations bears this out.

Under the essential fish habitat provisions found in the recent federal fisheries statutes, regional fisheries management councils were required to submit amendments to existing fishery management plans, which included the identification of essential habitat areas, identification of adverse impacts to essential habitat from both fishing and non-fishing sources, and identify measures to conserve and enhance this habitat (16 U.S.C. $\S 1853(\mathrm{a})(7))$. Upon approval of the essential habitat designations made by Councils, environmental organizations immediately began legal challenges based on the adequacy of the designations (see, American Oceans Campaign v. Daley, 183 F.Supp.2d 1 (D.D.C., 2000)). The main legal argument used by the environmental organizations (and the one found valid by the courts) was an inadequate impact and alternative analysis as required by NEPA. The environmental organizations also challenged the essential habitat designations under provisions of the Magnuson-Stevens Act, but the court held these designations were 
sufficient for purposes of the Magnuson-Stevens. What became a legal issue then, for both the environmental organizations bringing suit and the courts, was the quantity of review that was done by agencies to comply with the "hard look" doctrine under NEPA. Although the legal issues of science were raised under Magnuson-Stevens, the court dismissed any substantive review of the science supporting the designations. The court did find the agencies were under a duty to fully describe all activities under their habitat designations that could adversely impact the habitat, but there was little emphasis from the court scrutinizing the quality of scientific review, meaning the court did not delve deeply into the decision-making process by which the executive agency determined habitat to be essential. This was shown early on in the case of American Oceans Campaign v. Daley, 183 F.Supp.2d 1 (D.D.C., 2000).

In American Oceans, the district court focused entirely on NEPA analysis, indicating procedural irregularities that seemed to stem from essential fish habitat designation, and the corresponding duty to fully identify impact-activities, and once identified, to determine ways of limiting those activities. The actual identification of $\mathrm{EFH}$, including the scientific rigor used by NOAA Fisheries, was given deference by the court. As an example of this deference, the court noted the following:

Review of the Secretary's action must be especially deferential, given the highly complicated scientific data the agency must interpret. Where the agency decision turns on issues requiring the exercise of technical or scientific judgment, it is essential for judges to "look at the decision not as the chemist, biologist, or statistician that we are qualified neither by training or experience to be, but as a reviewing court exercising our narrowly defined duty of holding agencies to certain minimal standards of rationality." American Oceans Campaign, 183 F.Supp.2d at 11-12 (quoting Ethyl Corp. v. EPA, 541 F.2d 1, 36 (D.C. Cir. 1976)).

This deferential treatment by the court goes to the heart of the issue when considering habitat designations. The courts, as indicated in Chevron, will generally defer to agency expertise, where the legislative branch has not specifically defined "best available scientific information." Courts will not readily re-examine the science behind the EFH designation, but rather defer to the agency's reasonable interpretation. (An example of a reasonable Council interpretation may be found in 50 CFR $\S 600.815(\mathrm{a})(2)(\mathrm{i})(\mathrm{C})$ : an executive branch implementation rule that describes types of information Councils should gather and organize, but does not require Councils to collect new data when existing information is incomplete).

\subsection{How Judicial Deference Leads to Back-Ended Issues in Fisheries Management}

It is important to consider this distinction in the American Oceans Campaign opinion, because it is often cited as an example of judicial interpretation of "best science" issues for agencies (National Research Council, 2004). However, this interpretation is misplaced. Without clear congressional guidance on the issue, courts are likely to remain unwilling to substantively review the scientific rigor behind regional council's decisions to identify essential habitat, or scrutinize the appropriate management techniques employed to limit activities that might harm such habitat. What courts will likely do is hold agencies to account for their procedural review of information under NEPA. In doing so, courts may unwittingly be creating an incentive for the agency to become "new-science-adverse" in their decision-making. This is especially true when it comes to the after-effects of essential habitat designation. Once designated, federal law requires the proper "management" of the area, which is generally a protective philosophy (16 U.S.C. §Section 1853(a)(7) - identify and then minimize adverse effects). To comply with NEPA, agencies will have an easier administrative time defending status quo protective measures than analyzing new scientific research challenging initial designations of essential habitat. The lack of certainty, even with increased scientific rigor, will continually challenge agencies to comply with the full alternatives analysis, or "hard look" required under NEPA. Policy-wise, it may simply be more cost-effective to support existing designations through increased regulation (e.g., by-catch or gear restrictions), or to simply increase the size of existing closed areas. This may be done even when there is little to no scientific basis for the initial designation.

\section{Suggestions for Improving Decision-Making Within the Essential Fish Habitat Context}

As stated previously, most experts agree the main problem with habitat and ecosystem assessments is a lack of rigorous science at the outset to fully inform decision-making. However, evidence of overfishing, and the fear of habitat degradation from continued fishing activities has seemed to force the legislative branch into enacting laws aimed at ecosystem-based management. The mandate of identifying habitat and ecosystem features with less than sound science has created a serious accounting issue as the management regime moves forward. One reason for this is the "frameworks" in both policy and law from which current management of fisheries must develop. As shown in the American Oceans Campaign decision, courts have held fisheries agencies accountable for the timely designation of essential habitat. While the courts are unwilling to substantively challenge the 
scientific basis for designation, "hard look" judicial review of NEPA requires agencies quickly change their focus from reassessing the scientific basis of ecosystem-based boundaries to the work of creating limitations on fishing activities within those boundaries. To combat continuing lawsuits, a rational agency would seem to place their energies on meeting the procedural requirements of NEPA, focused primarily on gathering and using existing data, rather than refocusing their efforts on developing and analyzing scientific information aimed at exploring the foundations of essential fish habitat and spatial EFH designation in the first place. Where does this leave federal fisheries management? First, it seems to suggest identified boundaries, once drawn, remain in place. Second, this front-ended legal and regulatory framework creates incentives for agencies to move away from revisiting scientific underpinnings for decision, and instead move forward with refining regulatory compliance measures within defined areas. So, what measures in the front-ended process could be changed to create new incentives for implement better scientific assessment?

\subsection{Legislative Clarity on the Role of Science}

Most importantly, the legislative branch needs to take a more active role in controlling the quality of the scientific information that is required to inform policy decisions at the agency level. This recommendation contrasts with recent recommendations made by the National Academy of Sciences (National Research Council, 2004). However, we believe this is required to establish the correct framework for consideration and implementation of better scientific standards, especially in the identification and management of protected areas. What seems to be missed in attempting to understand agency decision-making is the regulatory framework in which agencies must operate. For instance, the historical review of essential habitat development suggests rapid executive agency designation activities. Since the judicial branch seems complacent to defer to the executive agency "scientific" basis for the EFH designation, there is little chance agencies will be forced by judicial pressure to re-examine the substantive scientific underpinnings. This leaves the legislative branch as the most logical place to reform the current trend. What we propose below are possibilities that have not been critically evaluated as potential alternatives to the current standard of defining "science" in fisheries management. We have identified a problem (labeled back-ended issues), but we have yet to develop any constructive policy review of alternatives (for a general understanding of policy analysis, see Bardach, 2008).

Congressional action on further refining the definition of "best available science" will make the legislative intent clear for judicial review purposes, and will thus give courts a better means of testing the appropriateness of agency decision-making in this area. Under a Chevron analysis, courts will be better equipped to discern congressional intent of scientific rigor, and thus, deferential review by the courts can be limited. This should remove many of the political aspects of EFH designation under NEPA review, and give agencies the freedom to place greater emphasis on evolving scientific research, which will likely lead to better adaptive management of fishery resources.

Under the Magnuson-Stevens Act, National Standard 2, which requires the use of best available science when making fishery management decisions, has been interpreted as requiring agency action even when there is insufficient scientific certainty. While this interpretation is likely necessary to engage in management despite a lack of science, it does little to persuade the inclusion of better science, whether that is in the form of research aimed at understanding the connections between spatial location and stock health, or whether it applies to a better analysis of available data. While the standard implies better science will inform management decisions in the future, the front-ended process of judicial deference under ambiguous congressional standards, and the "defensive" posture created through NEPA analysis makes the inclusion of better science less likely. This is compounded at the local level, where political influences can affect the honest assessment of "available" science at higher levels of decision-making. Without stronger congressional mandates on: (1) what "science" really means; (2) how much scientific certainty is required to inform the decision-making process; and (3) adaptive measures like sunset dates on decisions made with limited science, it is unlikely these major obstacles to fishery management will be overcome in the short-term. Congressional clarification will aid in minimizing many of the back-ended obstacles described above.

\subsection{Establishment of Ecosystem Science Committee}

Congress could implement greater clarification in a number of ways. To coincide with the fear of limiting scientific advancement through a specific congressional definition of "best science" (see, National Research Council, 2004), Congress could establish an ecosystems science commission, whose main function would be to develop specific standards on minimum levels of scientific certainty, and review new scientific research that may challenge (or alter) current designations. This committee would then be required to summarize the effect of the new science on habitat designations, and submit a summary to the appropriate Regional Council. The Council 
would then be required to make appropriate decisions (including modifications) based on this new science that has already been reviewed. The emphasis here would be on ensuring the "lines" being drawn were based on the best available science, and not subject to other competing concerns. While political compromise can occur in how to best manage fishery resources within designated areas, the actual designations themselves cannot be done outside the requirement of scientific rigor, especially when they are meant to describe essential ecosystem functions for a given species. To do so would arbitrarily assign fishing resource areas to greater levels of scrutiny. However, arbitrary designations do little to effectively manage a social resource.

\section{Conclusion}

Geospatial identification of marine habitats and ecosystem features is undoubtedly an important step in sustainable fishing practices. Since 1996, the United States has shifted its focus from a strict stock-assessment, to one focused on ecosystems and has increasingly employed geospatial management measures (e.g. Marine Protected Areas). We have identified back-ended issues resulting from application of the precautionary approach in the jurisprudential frameworks of the Magnuson-Stevens Fisheries Management Act and the National Environmental Policy Act. We suggest that congressional refinement of the terms and use of "science" and "scientific rigor" in fisheries management may better serve the Magnuson-Stevens Act goal of science-based management.

We are not advocating judge-scientists or challenging the philosophy of precaution. The actions we suggest are to deal with the unintended consequences (back-ended issues) arising from the interactions of NEPA procedures, executive branch precautionary approach to habitat and ecosystem management and the deferential standard of judicial review. We see the following critical back-ended issues: 1) Incentives to collect and merge all available information instead of selecting the best scientific information in order to satisfy the "hard look" NEPA standard; 2) disincentives for rigorous science review and evaluation of new information suggesting changes to existing essential fish habitat designations; 3) variable standards of scientific rigor which are highly influenced at the local level; and 4) pressure for executive agencies to use stock assessment survey data for purposes far beyond its scientific scope and design. Our greatest concern is the development of a body of judicial opinion subverting the "best available science" intentions of Congress.

The importance of this paper lies in the identification of a problem in current fisheries management. Further work should be established on developing alternative means of better integrating science into fisheries management, especially ecosystem-based management. The next step should be to establish specific criteria to critically analyze suggested alternatives.

\section{References}

Bardach, E. (2008). A practical guide for policy analysis: The eightfold path to more effective problem solving. Washington DC: CQ Press.

Coggins, G. (1998). Regulating federal natural resources: a summary case against devolved collaboration. Ecology Law Quarterly. 25, 602.

Greenberg, E. (1993). Ocean fisheries. In E. A. Campbell-Mohn (Ed.), Sustainable environmental law (pp. 376). New York, NY: West Publishing Co.

National Oceanic and Atmospheric Administration. (1999). Evolution, scope and current applications of the precautionary approach in fisheries (NOAA Technical Memorandum NMFS-F/SPO-40). Washington, DC: U.S. Government Printing Office.

National Oceanic and Atmospheric Administration. (2003). Final Amendment 13 to the Northeast Multispecies Fishery Management Plan, Including a Final Supplemental Environmental Impact Statement and an Initial Regulatory Flexibility Analysis. 50 CFR Part 648.

National Oceanic and Atmospheric Administration. (2005). Developing regional marine ecosystem approaches to management (NOAA Technical Memorandum NMFS-F/SPO-77). Washington, DC: U.S. Government Printing Office.

Murawski S. A., Brown R., Lai H. L., Rago P. J., \& Hendrickson L. (2000). Large-scale closed areas as a fishery-management tool in temperate marine ecosystems: the Georges Bank experience. Bulletin of Marine Science. 66, 775-798.

National Research Council. (2002). Science and its role in the National Marine Fisheries Service. Washington, DC: National Academy Press. 
National Research Council. (2004). Improving the use of the "best scientific information available" standard in fisheries management. Washington, DC: National Academy Press.

National Research Council. (2006). Dynamic changes in marine ecosystems: fishing, food webs, and future options. Washington, DC: National Academy Press.

Pikitch, E.K., Santora, C., Babcock, E.A., Bakun, A., Bonfil, R., Conover, D.O.,...Sainsbury, K.J. (2004). Ecosystem-based fishery management. Science, 305, 346-347.

Sissenwine, M. M. (2003). Governance for responsible fisheries: an ecosystem approach. In V. G. Sinclair (Ed.), Responsible fisheries in the marine ecosystem (pp. 363-392). Cambridge, MA: CABI.

\section{Notes}

Note 1. Essential fish habitat generally refers to habitat necessary to support the life-cycle of a particular commercial fish species. The premise for management purposes being that if essential fish habitat can be identified, then management can incorporate ecosystem-based principles. This might mean, for instance, protecting an area from fishing to preserve important breeding grounds of a commercially important fish species. When scientific information is lacking, it is generally left to the agency to interpret what is essential fish habitat. Thus, if the legislative branch passes a law requiring the identification and protection of essential fish habitat, the ultimate determination of this habitat may be arbitrary. The primary way to challenge an agency decision claimed to be arbitrary would be in requesting review by the judicial branch. Thus, the rules used by the judicial branch in determining whether the agency decision in identifying essential fish habitat becomes critical in ensuring the agency is acting within the powers (intent) granted by the legislative branch.

Note 2. The National Environmental Policy Act, or NEPA, is a United States federal law that was enacted in 1970 to ensure all major federal actions that might have a significant impact on the environment are reviewed prior to the action taking place. The review is essentially environmental in nature, generally consisting of an assessment of the potential environmental impacts of the proposed project. Included in this assessment is not only the identification of potential environmental impacts, but also an analysis of alternatives to the project that may further minimize potential environmental impacts. Included in this "alternatives" analysis is a consideration of taking no action towards the project. While NEPA does not prevent a project from moving forward, it does require a "hard look" at the potential environmental impacts. NEPA impacts fisheries management because each fishery management plan that is developed is also subject to NEPA review, meaning the fisheries management plan must also consider the potential environmental impacts.

Note 3. Essential habitat is being used in this context to refer to habitat necessary for the life-cycle of the fish species. For example, a breeding ground would be evidence of essential fish habitat. However, the breeding ground is not necessarily the same location fish species are found during NOAA trawl surveys which typically take place only during a few weeks every year. Much of the research used to establish fish habitat associations is based on presumed cooccurance of identifying a particular fish species and some habitat feature. While informative, this information is circumstantial and does not necessarily support a causal connection. This suggestion here is that much of the available data being used to identify essential fish habitat is not appropriate for making "scientific" designations.

Note 4. It is congressional policy to assure that the national fishery conservation and management program utilizes and is based upon the best scientific information available - 16 U.S.C. §1801(c)(3). Further, Magnuson-Stevens specifically requires that "[c]onservation and management measures shall be based upon the best scientific information available” - 16 U.S.C. $§ 1851(a)(2)$. 


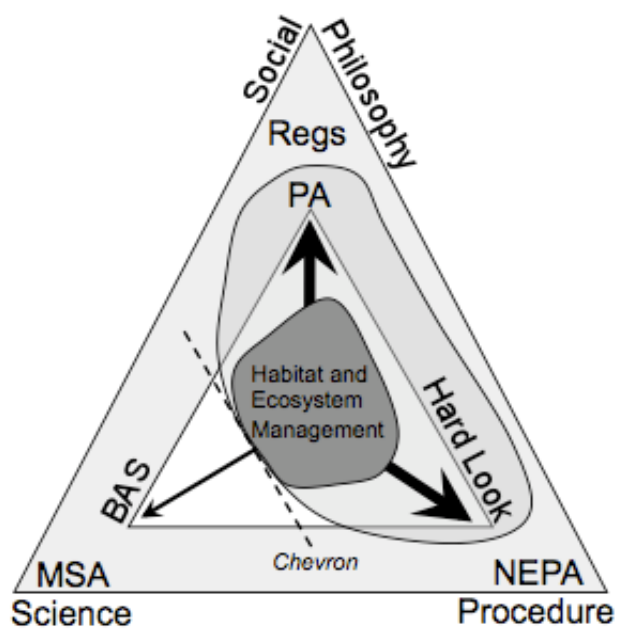

Figure 1. Conceptual rendering of "drivers" in U.S. Fisheries management

There are two primary federal laws at stake, the Magnuson-Stevens Fishery Act focusing primary on science as a "driver" of decision-making; and the National Environmental Policy Act (NEPA) focusing primary on ensuring the procedural review of environmental impacts. While Magnuson-Stevens requires a "Best Available Science" (BSA) standard, judicial case precedent (most notably the Chevron case) limits the judicial branch's review of science supporting fisheries management decisions through the doctrine of deference. Other "drivers" influencing federal fisheries management include the social and philosophical approaches of those who inhabit the federal fisheries management agency at a given time. These preferences can be seen in the regulations (Regs) adopted by the agency to implement federal fishery law, which are influenced by factors such as a precautionary approach (PA) to fisheries management. The suggestion in the figure, represented by the weight of the arrows, is that federal fisheries management is mainly focused on complying with NEPA procedural requirements, and this is done mainly through regulations imbued with precautionary language, but not necessarily based on sound scientific principles. 